\title{
EFFECTS OF UNANI ANXIOLYTICS (SOMINA) ON GENERAL REPRODUCTIVE PERFORMANCE AND TERATOLOGY IN RATS
}

\author{
MUHAMMAD AHMED ${ }^{1 *}$, AISHA AZMAT² \\ 1*Department of Pharmacology and Toxicology, Faculty of Pharmacy, Umm Al-Qura University. P. 0. Box. 13578. Makkah, Saudi Arabia, \\ 2Department of Physiology, Faculty of Medicine, Umm Al-Qura University, P. 0. Box 7607 Makkah, Saudi Arabia
}

Email: hma00ahmed@hotmail.com

Received: 14 Nov 2016 Revised and Accepted: 09 Jan 2017

\begin{abstract}
Objective: Somina (herbal medicine) is used in Pakistan as Unani anxiolytics. It is composed of five medicinal plants. The current work was designed to evaluate the general reproductive and teratogenic effects of somina in two consecutive generations of rats according to the OECD guideline.

Methods: Fertility study (a two-phase study) was done in Sprague-Dawley rats. 1st part: three groups' female rats (10 rats each group) received different doses orally. First group: The control group (saline), a single oral human dose of somina ( $2^{\text {nd }}$ group: $\left.285 \mathrm{mg} / \mathrm{kg} / \mathrm{day}\right)$ and the high dose of somina ( $3^{\text {rd }}$ group: $1 \mathrm{~g} / \mathrm{kg} /$ day) during the whole period of gestation till the delivery of pups named as F1 Breed. For the second part of study ten females were selected from each F1 breed (control, somina $285 \mathrm{mg} / \mathrm{kg} / \mathrm{d}$, somina $1 \mathrm{~g} / \mathrm{kg} / \mathrm{day}$ ) and administered the same treatment from day first of mating than the entire period of gestation until F1 breed delivered pups (F2 breed). For F1 and F2 breed the fertility index and litter size were determined. Some of the female rats (F1 and F2) were anesthetized and autopsied. The blood sample was subjected to biochemical analysis and serum liver function test: bilirubin, gamma-glutamyl transferase $(\gamma \mathrm{GT})$, alanine aminotransferase (ALT: SGPT), aspartate aminotransferase (AST: SGOT) and alkaline phosphatase (ALP) were measured spectrophotometrically. The uterine growth index, fertility index, and litter size were also measured to evaluate the teratogenic effects of somina treated rats.
\end{abstract}

Results: The data showed that any significant different $(\mathrm{P}>0.05)$ was not found during the maternal examination (uterine growth index, fertility index) and reproductive parameters (litter size, the quantity of fetus, aborted or absorbed fetus) in somina treated rats as compare to control rats $(\mathrm{P}>0.05)$. Control and treated Pups did not show any significant $(\mathrm{P}>0.05)$ malformation and any congenital defects. Non-significant $(\mathrm{P}>0.05)$ changes were observed in liver function test. It was found normal in all groups. Macroscopic autopsy examination also did not reveal any significant $(\mathrm{P}>0.05)$ pathological findings in the liver, kidneys, and uterus.

Conclusion: The oral administration of somina during the gestational period of pregnant female rats was not teratogenic/fetotoxic. Any adverse or deleterious effects were not observed at the dose of $285 \mathrm{mg} / \mathrm{kg}$ (human dose) or $1 \mathrm{~g} / \mathrm{kg}$ (3times greater than the human dose) during pregnancy, and it is safe in rats.

Keyword: Somina, Teratogenic activity, Two-generation reproductive toxicity, F1 breed, F2 breed, Uterine growth index, Fertility index

(C) 2016 The Authors. Published by Innovare Academic Sciences Pvt Ltd. This is an open access article under the CC BY license (http://creativecommons.org/licenses/by/4. 0/) DOI: http://dx.doi.org/10.22159/ijpps.2017v9i3.16182

\section{INTRODUCTION}

Somina is herbal medicine prepared by Hamdard Laboratories (waqf) in Pakistan. It is available in powder form and consists of five medicinal plants that are Sesamum indicum (14\%), Lagenaria vulgaris $(12 \%)$, Prunus amygdalus $(12 \%)$, Papaver somniferum (10\%) and Lactuca scariola (5\%). It is used as curative unani anxiolytics in Pakistan $[1,2]$ also to strengthen all processes involved in memory and learned behaviour [3]. The role of somina in alternative medicine as curative unani anxiolytic is appealing because it is easily available and cheap. Natural herbs have vital medical importance [4, 5] and are being used in alternative medicine. Hakims (herbalists) have been practicing and describing these natural herbs or herb based formulation for ages. These herbal medicines may contain either one or mixture of different herbs or extracts for health benefits $[6,7]$.

However, these alternative herbal medicine has a risk of toxicity for human $[8,9]$. There is some evidence of harm of traditional herbal medicines [10] either used singly or as poly-herbal. Regarding the safety of herbal medicine, information is contradictory. Therefore, In different countries, to make the use of herbal medicines safer and legislation for these products has undergone changes in recent years, and pharmaceutical companies are instructed to submit data on the efficacy and safety of herbal medicines [11]. Previously, according to Hodge and Sterner toxicity scale, the obtained value of the lethal dose (LD) $50>10,000 \mathrm{mg} / \mathrm{kg}$ classified the somina as practically non-toxic herbal medicine [12]. However, the drawbacks that might be affiliated with somina during pregnancy have not been investigated. Reproductive performance and teratogenicity of some medicinal plants expose the fact that some herbs or plants did not have any side effect. That's why, it is time to conduct safety studies and teratogenic study of somina in its standardized form and provides authenticated proved literature to guide the population about the use of somina, and clarify the side effects of somina, especially in pregnancy. The objective of this research was to observe the teratogenic effect of somina and safety of this drug during pregnancy in rats.

\section{MATERIALS AND METHODS}

\section{Somina}

Somina drug was received from Hamdard Laboratories (Waqf) Pakistan. Two doses of somina $285 \mathrm{mg} / \mathrm{kg} / \mathrm{d}=$ human dose and $1 \mathrm{~g} / \mathrm{kg} / \mathrm{d}=3$ times greater than the human dose was calculated and prepared for administration.

Human dose of somina $=$ two tablespoon twice a day $=20 \mathrm{~g} /$ day

$20 \mathrm{~g} /$ day $=285 \mathrm{mg} / \mathrm{kg} /$ day

\section{Chemicals and reagents}

All biochemical tests were performed by using commercial assay kits. Kits used were: Mercko test $₫$ for bilirubin, Ecoline $₫ 25$ for SGPT. Ecoline ${ }^{\circledR}$ S+by Szasz method for $\gamma \mathrm{GT}$, Ecoline ${ }^{\circledR} 25$ for ALP, Ecoline ${ }^{\circ} 125$ for ASAT (GOT). 


\section{Animals}

Adult primiparae Sprague-Dawley rats (>3months: 150-200) were used. Animals fed with standard rodent diet and water ad libitum, and were housed and looked after according to the animal house committee regulations on "the care of experimental Animals." The study regarding general reproductive performance and teratology in rats was performed according to guidelines approved by food and drug administration (FDA) for reproduction studies [13, 14]. The Institutional ethic committee approved the study (Approval number: Reg no.2005/04/S/HMIIPHS)

\section{Grouping or design of study}

The teratological study was performed according to established methods $[15,16]$ with slight modifications.

\section{Implantation and fertility study}

The study regarding general reproductive performance and teratology in rats was performed according to guidelines approved by FDA reproduction studies $[13,14]$.

The current work was conducted in two phases as described earlier [16]:

Phase I: 30 primiparous female rats +6 male rats were used for teratogenic activity

The rats were divided as follows,

Group 1: 10 control females were treated with distilled water from day 0 until pups delivery

Group 2: 10 control females were treated with somina (285 $\mathrm{mg} / \mathrm{kg} / \mathrm{d}=$ human dose) from day 0 until pups delivery

Group 3: 10 control females were treated with somina $(1 \mathrm{~g} / \mathrm{kg} / \mathrm{d}=3$ times greater than human dose) from day 0 until pups delivery

At day 0 , male and female both received the first dose and then five primiparae females were kept in the cages with one male rat. Control females were kept overnight with control male and treated female rats were paired with treated male rats.

\section{Confirmation of pregnancy}

Mating was confirmed by the presence of sperm in the vagina the following morning $(09 \mathrm{H}-10 \mathrm{H})$ and this day was considered as day 1 of pregnancy. After that day, all female rats were regularly monitored, administered the dose and were weighed daily. On the 10th day of gestation, the significant increase in weight has confirmed the pregnancy. The doses were continued till the delivery [16].

Delivered pubs were considered as control and somina treated F1 breed. After the completion of the work, the litter size was noted, and the fertility index calculated using the following formula [17]:

$$
\text { Fertility index }=\frac{\text { Number of Pregnant } \mathrm{x} 100}{\text { number of mated }}
$$

The goal of this study was to enumerate the quantity of delivered pups (F1 Breed for control: for Somina $285 \mathrm{mg} / \mathrm{kg}$ and Somina $1 \mathrm{~g} / \mathrm{kg}$ ) for further statistics. Female rats were dissected if weight did not gain significantly to observe the resorption sites. For each delivered pups, a malformed structure was also noticed. Pups were individually marked when weaned. For eight weeks, the F1 breed was nurtured, and mortality was noted. After eight weeks received the first dose and mated again to obtain F2 breed in part two study [16].

Phase II: 30 Female rats+ 6 male rats from F1 generation (delivered pups when they matured) were used for second phase teratogenic activity

Group 1: 10 Control females from F1 breed were selected randomly and were treated with distilled from day 0 before mating until they delivered pups

Group 2: 10 females from F1 breed have been chosen randomly and treated with Somina $(285 \mathrm{mg} / \mathrm{kg} / \mathrm{d})$ from day 0 before mating until they delivered pups

Group 3: 10 females from F1 breed were selected randomly and treated with Somina $(1 \mathrm{~g} / \mathrm{kg} / \mathrm{d})$ from day 0 before mating until they delivered pups

All experimental procedure was same as done in phase 1 study. At the end of the study, the litter size was recorded, and the fertility index calculated using the following formula [17]:

$$
\text { Fertility index }=\frac{\text { Number of Pregnant } \times 100}{\text { number of mated }}
$$

After six weeks, six rats from each breed F1 and F2 were sacrificed, and their blood samples were was subjected to liver function test, and animals were autopsied [18].

\section{Liver function test}

After six weeks, six rats from each breed F1 and F2 were sacrificed, and the blood samples approximately ( 5 to $8 \mathrm{ml}$ ) were withdrawn from cardiac punctures from treated (F1 and F2) and control rats (F1 and F2). Blood samples were left at room temperature for $20 \mathrm{~min}$, then incubated at $37{ }^{\circ} \mathrm{C}$ for $30 \mathrm{~min}$ and centrifuged separately in (BHG) Hermle Z230 (Germany) at the speed of 3,000 rpm for $20 \mathrm{~min}$. Serum obtained (1 to 3 $\mathrm{ml}$ ) was subjected for the study of the liver function test parameters: Bilirubin, gamma glutammyl transferase $(\gamma \mathrm{GT})$, alkaline phosphatase (ALP), aspartate aminotransferase (ASAT, SGOT) and alanine aminotransferase (ALT: SGPT). All tests were performed by using commercial assay kits. Kits used were: Mercko test $₫$ for bilirubin, Ecoline ${ }^{\circledR} 25$ for SGPT, Ecoline ${ }^{\circledR}$ S+by Szasz method for $\gamma$ GT, Ecoline $₫$ 25 for ALP, Ecoline ${ }^{\circledR} 125$ for ASAT (GOT). All these kits were purchased from diagnostic Merck (Germany). U-2000 spectrophotometer (Hitachi) was used to measure the absorbance of light.

\section{RESULTS}

\section{Effect of somina on implantation and fertility index}

Table 1 stated the results of the pre-coital administration of distilled water and two different doses of somina in rats (female). Treatmentinduced pathological signs was not observed in any group. Compared to the control, somina $(285 \mathrm{mg} / \mathrm{kg}$ or $1 \mathrm{~g} / \mathrm{kg})$ did not show any significant implantation failure or inadequate uterine receptivity $(P>0.05)$. All treated female rats become pregnant after successful mating. The fertility index was not affected and found to be $100 \%$ in all groups used in part 1 and F1 breeds used in part II (table 1). During full gestation periods, all females (control and somina treated) showed a significant increase in weight $(\mathrm{P}<0.05)$. The doses were continued till the delivery.

Table 1: Effects of somina on implantation and fertility of adult female rats

\begin{tabular}{llll}
\hline Treatments & Implantation & & Fertility \\
\cline { 2 - 4 } & Sperm positive female & Implanted females & Fertility Index \\
\hline Part 1 & 10 & 10 & $100 \%$ \\
G1 & 10 & 10 & $100 \%$ \\
G2 & 10 & 10 & $100 \%$ \\
G3 & & & \\
Part II (F1 breed) & 10 & 10 & $100 \%$ \\
G2 & 10 & 10 & $100 \%$ \\
G3 & 10 & 10 & $100 \%$ \\
\hline
\end{tabular}

Values are expressed as percentage. $\mathrm{n}=10$ female rats per group were randomized. G1-control, G2 somina- $285 \mathrm{mg} / \mathrm{kg} / \mathrm{d}, \mathrm{G} 3-\mathrm{somina} 1 \mathrm{~g} / \mathrm{kg} / \mathrm{d}$ 


\section{Reproductive parameters (embryo-fetal examination)}

However, during the whole gestational period, any abortions were not noted in all groups. All cages were checked daily but did not find any aborted or absorbed fetuses from the control group and somina treated group.

At the time of delivery, nonsignificant variations $(\mathrm{P}>0.05)$ were observed in quantity of fetus. A total number of collected pups from control and somina $(285 \mathrm{mg} / \mathrm{kg} / \mathrm{d}$ or $1 \mathrm{~g} / \mathrm{kg} / \mathrm{d}$ ) treated group (F1 generation) were 58,56 and, 63 respectively. While in the F2 generation, the number of pups from control was 62. somina (285 $\mathrm{mg} / \mathrm{kg} / \mathrm{d}$ or $1 \mathrm{~g} / \mathrm{kg} / \mathrm{d}$ ) treated female delivered 66 and 72 pups respectively as presented in table 1 .

\section{Fetal malformations and variations}

Delivered pups (F1 and F2 breeds) were monitored for any gross abnormality, and the result indicated that pups in all groups did not have any congenital malformations as showed in fig. 1 and table 2 . External examination (fig. 1) did not reveal any abnormal findings concerning length, cranium, eyes, palate, limbs, tail, genitals, and sex.

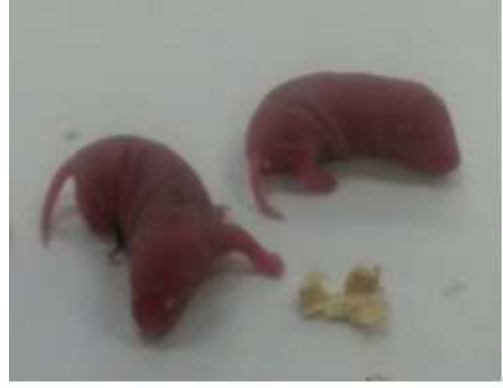

Fig. 1a. Control pups F1 breed

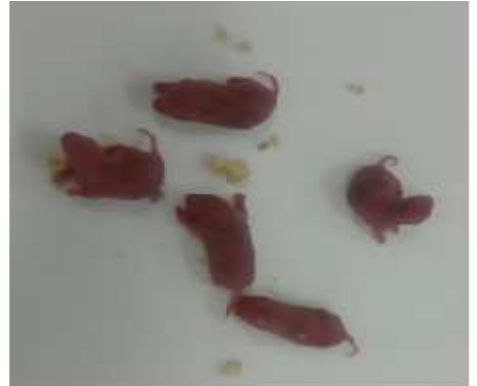

Fig.1b. Somina treated $(285 \mathrm{mg} / \mathrm{kg} / \mathrm{d})$ pups F1 breed

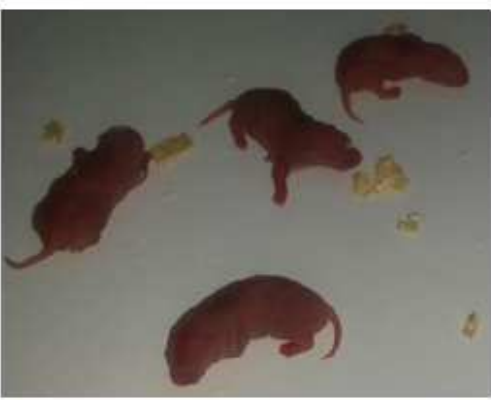

Fig.1c. Somina treated $(1 \mathrm{~g} / \mathrm{kg} / \mathrm{d})$ pups $\mathrm{F} 1$ breed

Fig. 1: a. Control pups F1 breed, b. Somina treated ( $285 \mathrm{mg} / \mathrm{kg} / \mathrm{d})$ pups F1 breed, c. Somina treated (1g/kg/d) pups F1 breed

Table 2: Teratogenic activity of somina (herbal drug) in rats

\begin{tabular}{|c|c|c|c|c|c|c|}
\hline & \multicolumn{3}{|c|}{ F1 generation } & \multicolumn{3}{|c|}{ F2 generation } \\
\hline & G1 & G2 & G3 & G1 & G2 & G3 \\
\hline Aborted or absorbed fetuses & 0 & 0 & 0 & 0 & 0 & 0 \\
\hline Total number of pups & 58 & 56 & 63 & 62 & 66 & 72 \\
\hline Gross congenital malformation & no & no & no & no & no & no \\
\hline
\end{tabular}

Values are expressed as total. $\mathrm{n}=10$ female rats per group. G1-control, G2 somina- $285 \mathrm{mg} / \mathrm{kg} / \mathrm{d}$, G3-somina1g/kg/d

\section{Biochemical parameters}

Pre-coital administration of distilled water and two different doses of somina in rats was continued till the delivery of pups. At the sixth week, randomly six rats from each delivered breed (F1 and F2 generation) were subjected to biochemical analysis (LFT). The results were presented in table 3. Liver function test (LFT) results showed that somina $(285 \mathrm{mg} / \mathrm{kg} / \mathrm{d}$ or $1 \mathrm{~g} / \mathrm{kg} / \mathrm{d})$ did not show any significant changes $(\mathrm{P}>0.05)$ in different liver marker enzymes (table 3). The levels were comparable to its control.

Table 3: Effect of Somina on different liver enzymes

\begin{tabular}{llllll}
\hline Parameters & F1 generation & & & \multicolumn{2}{l}{ F2 generation } \\
\cline { 2 - 6 } & G1 & G2 & G3 & G1 & G2 \\
\hline Bilirubin & $1.6+0.15$ & $0.86+0.6$ & $0.98+0.2$ & $1.26+0.1$ & $1.32+0.56$ \\
$\gamma$ GT & $4.26+0.95$ & $6.48+1.2$ & $6.2+2.95$ & $5.95+1.26$ & $6.48+1.2$ \\
ALT: SGPT & $18.85+0.5$ & $19.58+3.6$ & $13.68+1.0$ & $19.85+2.4$ & $22.58+5.5$ \\
AST: SGOT & $22.09+1.2$ & $24.26+0.6$ & $21.61+3.6$ & $27.21+1.6$ & $27.27+0.9$ \\
ALP & $15.9+2.5$ & $14.13+2.2$ & $15.62+2.9$ & $20.05+1.9$ & $23.68+5.2$ \\
\hline
\end{tabular}

Values are expressed as mean \pm SE. Non-significant difference against control group, $\mathrm{n}=6$ female rats per group were randomized. G1-control, G2 somina-285 mg/kg/d, G3-somina $1 \mathrm{~g} / \mathrm{kg} / \mathrm{d}$. $\gamma$ GT-gamma glutamyl transferase, ALT: SGPT-alanine aminotransferase, AST: SGOT-aspartate aminotransferase, ALP-alkaline phosphatase 


\section{Autopsy}

An autopsy stated that any abnormal lumps and lesions were not witnessed in any part of the body after examining the whole body, especially in the uterus. The texture of the uterus, liver, kidney and heart was comparable to normal. All vital organs were intact and did not show any sign of toxicity.

\section{DISCUSSION}

Many anxiolytic drugs are associated with many side effects especially teratogenic effects which decrease their clinical utility [19]. Therefore, the use of medicinal plants for neurological and psychiatric diseases has progressed significantly owing to their fewer side effects and better reliability [20]. The aim of the present study was to evaluate the implantation, fertility index and teratogenic properties of somina, a unani anxiolytic in rats. Two different doses of somina $(285 \mathrm{mg} / \mathrm{kg} / \mathrm{d}$ or $1 \mathrm{~g} / \mathrm{kg} / \mathrm{d})$ were used in this study. Previously, Ahmed [12] has reported that somina is practically nontoxic unani anxiolytic medicine, but the teratogenic effect of somina was not evaluated. The present study suggests that somina did not produce any harmful teratogenic effects in rats. In literature, individual constituents of somina were reported to have potential fertility property, Sesamum indicum in male rats $[21,22]$ and Prunus amygdalus [23]. The present study confirmed that somina as a whole did not cause any teratogenic effect. In the present study, pre-coital administration of somina (at both doses) in female rats was assessed because the precoital antifertility effects of neem oil have been confirmed [24].

However, in current study pre-coital administration did not provoke any failure of implantation (table 1). All female rats become pregnant, and fertility index was 100\% (table 1). Fertility index and implantation in somina treated rats are in agreement with previous studies [21-23]. More important is the fact that somina is used during the widow period when the growing fetus is most sensitive to teratogens, week 38 [25]. None of the treated breed showed any malformation.

The results obtained suggested that somina did not produce any significant changes in gross behavior, autopsy [12] and liver function test (LFT) in rats (table 3). Our study is in agreements of previous studies suggest that different constituents of Somina Like sesame [26], Prunus amygdalus [27], Lagenaria vulgaris [28] and Lactuca scariola [29] individually, can be used without any adverse effect on liver function and protect the liver from oxidative damage [26]. In both generations, parameters regarding the LFTs are normal. The administration of somina $(10 \mathrm{~g} / \mathrm{kg})$ was safe as no mortality was observed [12]. In the present study, somina is also safe during pregnancy in rats.

\section{CONCLUSION}

Two-generation reproductive toxicity (F1 and F2 breed) study concludes that continuous administration of herbal drug somina during implantation and pregnancy did not show any maternal and fetal toxicity. It did not lead to fetal growth retardation or fetal death or any teratogenic effects. It is recommended that the oral dose of $1 \mathrm{~g} / \mathrm{kg} / \mathrm{d}$ was found to be safe during the gestational period in pregnant rats.

\section{Ethical approval}

Authors hereby declared that principles of laboratory animal care (NIH publication No. 85-23, revised 1985) were followed, as well as specific national laws where applicable. All experiments have been examined and approved by the departmental ethics committee" (Approval number: Reg no.2005/04/S/HMIIPHS)

\section{ACKNOWLEDGEMENT}

The authors are grateful to Prof. S. I. Ahmed (late) former Dean, Faculty of Pharmacy, University Of Karachi, Hamdard University Karachi and Director of HMIIPHS, Hamdard University Karachi for his support, encouragement at every step of this study.

\section{CONFLICT OF INTERESTS}

The authors have no conflict of interest

\section{REFERENCES}

1. Khan U, Hannan A, Mohiuddin E, Sarwar MK. Herbal medicine and anxiety disorders. Health Sci Res Eastern Med 2008. p. 1928.

2. Azmat A, Ahmed M, Zafar N, Ahmad SI. Neuropharmacological profile of Somina (Herbal Drug) in mice and rats. Pakistan J Pharmacol 2008;25:53-8.

3. Azmat A, Ahmed M, Haider S, Haleem DJ, Zafar N, Ahmad SI. Enhanced memory processes under the influence of herbal drug Somina and its effect on brain serotonin. Afr J Pharm Pharmacol 2012;6:2458-63.

4. Jyoti A, Anand K, Sunanda P. Synergistic action of phytochemicals augments their antioxidative efficacy: an in vitro comparative study. Asian J Pharm Clin Res 2013;6 Suppl 4:121-6.

5. Deshpande P, Mohan V, Pore M, Gumaste S, Thakurdesa P. Prenatal developmental toxicity evaluation of Furostanol Saponin Glycoside based standardised fenugreek seed extract during organogenesis period of pregnancy in rats. Int J Pharm Pharm Sci 2016;8:124-9.

6. Agarwal S, Jain A, Jain A, Mourya M, Vandana KC, Jackson P, et al. N-Astheal $\AA$, A herbal formula for the treatment of mild asthma: an open, single-centric, noncomparative pilot study for 3 W. Asian J Pharm Clin Res 2014:7:1-6.

7. Walker R. Criteria for risk assessment of botanical food supplements. Toxicol Lett 2004;149:187-95.

8. Palmer ME, Haller C, McKinney PE, Klein-Schwartz W, Tschirgi A, Smolinske SC, et al. Adverse events associated with dietary supplements: an observational study. Lancet 2003;361:101-6.

9. Pittler M, Ernst E. Systematic review: hepatotoxic events associated with herbal medicinal products. Aliment Pharmacol Ther 2003;18:451-71.

10. Garba SH, Jacks TW, Onyeyili PA, Nggada HA. Embryofetal effects of the methanolic root extract of Cissampelos Mucronata A. rich in rats. J Anamtomy 2014;3:286-93.

11. Turolla MSR, Nascimento ES. Informações toxicológicas de alguns fitoterápi cosutiliza dos no Brasil. Rev Bras Ciên Farm 2006;42:289-306.

12. Ahmed M. Acute toxicity (Lethal Dose 50 Calculation) of herbal drug Somina in rats and mice. Pharmacol Pharm 2015;6:185-9.

13. FDA. Toxicological Principles for the Safety of Food Ingredient 'Redbook'. US Food and Drug Administration Centre for Food Safety and Applied Nutrition, Washington DC; 2000.

14. Pfannkuch F, Edwards JA, Wolz E, Marsden E. EGCG (Ro 267624/000)--two generation oral (dietary admixture) reproduction toxicity study in the rat. Roche Vitamins Ltd; 2002 a.

15. Isbrucker RA, Edwards JA, Wolz E, Davidovich A, Bausch J. Safety studies on epigallocatechin gallate (EGCG) preparations. Part 3: teratogenicity and reproductive toxicity studies in rats. Food Chem Toxicol 2006;44:651-61.

16. Ahmed M, Azmat A. Two-generation reproductive toxicity study of Barrisal (Herbal Drug) on the sprague dawley rats. Annu Rev Res Biol 2014;4:3197-202.

17. Ratnasooriya WD, Dharmasiri MG. Effects of Terminalia catalpa seeds on sexual behaviour and fertility of male rats. Asian J Androl 2000;2:213-9.

18. Kurtz SM. Toxicological studies on Gemfibrozil. Proc Roy Soc Med 1976;69 Suppl 2:15-23.

19. Pawson P.Sedatives. In: Small animal clinical pharmacology (2nd edn). Maddison J, Page S, Church D. eds. Saunders (Elsevier), UK; 2008. p. 113-25.

20. Zhang ZJ. Therapeutic effects of herbal extracts and constituents in animal models of psychiatric disorders. Life Sci 2004;75:1659-99.

21. Ashamu EA, Salawu EO, Oyewo 00, Alhassan AW, Alamu OA, Adegoke AA. Efficacy of vitamin $\mathrm{C}$ and ethanolic extract of Sesamum indicum in promoting fertility in male Wistar rats. J Hum Reprod Sci 2010;3:11-4.

22. Mahabadi JA, Bafrani HH, Nikzad H, Taberian A, Salehi M. Effect of diet contains sesame seed on adult wistar rat testis. Int J Morphol 2013;31:197-202. 
23. Hari JR, Lakshmi. Therapeutic applications of almonds (Prunus amygdalus L): a review. J Clin Diagnostic Res 2012;6:130-5.

24. Bardhan J, Riar SS, Sawhney RC, Kain AK, Thomas P. Iiavazhagan $G$. Neem oil: a fertility controlling agent in Rhesus monkey. Indian J Physiol Pharmacol 1991;35:278-80.

25. Sadler TW. Susceptible periods during embryogenesis of the heart and endocrine glands. Environ Health Perspect 2000;108 Suppl 3:555-61.

26. Sirato-Yasumoto N, Katsuta M, Okuyama Y. Effect of sesame seed rich in sesamin and sesamolin on fatty acid oxidation in rat liver. J Agric Food Chem 2001;49:2647.

27. Soni M, Mohanthy PK, Jaliwala YA. The hepatoprotective activity of the fruits of Prunus. Int J Pharm Biosci 2011;2:439-52.
28. Funde SK, Jaju JB, Dharmadhikari SC, Pawar GR. Effect of Lagenaria siceraria fruit extract (Bottle gourd) on hepatotoxicity induced by antitubercular drugs in albino rats. Int J Basic Clin Pharmacol 2013;2:728-34.

29. Hefnawy TM, Ramadan MF. Protective effects of Lactuca sativa ethanolic extract on carbon tetrachloride-induced oxidative damage in rats. Asian Pac J Trop Dis 2013;3:27785 .

\section{How to cite this article}

- Muhammad Ahmed, Aisha Azmat. Effects of unani anxiolytics (Somina) on general reproductive performance and teratology in rats. Int J Pharm Pharm Sci 2017;9(3):30-34. 